\title{
Respiratory and systemic reaction following exposure to heated electrostatic polyester paint
}

\author{
A. Cartier*, O. Vandenplas*, L.C. Grammer**, M.A. Shaughnessy**, J-L. Malo*
}

Respiratory and systemic reaction following exposure to heated electrostatic polyester paint. A, Cartier, O. Vandenplas, L.C. Grammer, M.A. Shaughnessy, J-L. Malo. CERS Journals Ltd 1994.

ABSTRACT: A 39 year old nonatopic man developed episodes of cough, dyspnoea, sweating and shivers within 2-3 weeks of starting a new job in a factory where metallic boards were treated with an electrostatic powder paint, made of an epoxy resin and a carboxylated polyester containing polyethylene terephthalate and polybutylene terephthalate. The subject sprayed the metallic boards which were then heated in $200^{\circ} \mathrm{C}$ ovens.

The subject was first seen in an emergency room after being at work for $4 \mathrm{~h}$. The physical examination revealed bilateral wheezing with fever $\left(39^{\circ} \mathrm{C}\right)$, hypoxaemia (arterial oxygen tension $\left(\mathrm{Pao}_{2}\right) 58$ torr $(7.7 \mathrm{kPa})$, leucocytosis (white blood count cells $\mathrm{mm}^{-3} 17,000\left(17 \times 10^{9}\right.$ cells $\left.\cdot l^{-1}\right)$ and severe airway obstruction (forced expiratory volume in one second $\left(\mathrm{FEV}_{1}\right)$ /forced vital capacity, (FVC) $1.3 / 2.4 l$, improving to 2.2/3.8 $l$ after bronchodilator; predicted values $=3.4 / 4.1 l$ ). The subjects condition improved after being treated with oral steroids. His spirometry was normal two weeks later, although he showed mild bronchial hyperresponsiveness to methacholine with the (provocative concentration producing a $20 \%$ fall in $\mathrm{FEV}_{1}\left(\mathrm{PC}_{20}\right)$ being $\left.1.7 \mathrm{mg} \cdot \mathrm{ml}^{-1}\right)$.

The subject underwent specific inhalation challenges at the workplace 4 months later. After being exposed at work for $4 \mathrm{~h}$, he developed a significant fall in $\mathrm{FEV}_{1}(\mathbf{- 4 0 \%})$, fever, leucocytosis, and a fall in diffusing capacity. Lung function tests were back to normal two weeks later. Exposing the subject to heated granulated polyester for one hour in a hospital laboratory produced a fall in $F V_{1}$ of $41 \%$, fever, leucocytosis and a fall in diffusing capacity. Nine months later, the subject still had symptoms of mild asthma and his $\mathrm{PC}_{20}$ was $0.2 \mathrm{mg} \cdot \mathrm{ml}^{-1}$.

To the best of our knowledge, this is the first account of occupational asthma and an alveolitis-type reaction after exposure to polyester.

Eur Respir J., 1994, 7, 608-611.
*Dept of Chest Medicine, Hôpital du SacréCoeur, Montreal, Canada. **Dept of Medicine, Northwestern University, Chicago, USA.

Correspondence: J-L. Malo

Dept of Chest Medicine

Sacré-Coeur Hospital

5400 West Gouin

Montreal

Canada H4J 1C5

Keywords: Allergic alveolitis (extrinsic) bronchial provocation tests

hypersensitivity pneumonitis

occupational asthma

occupational diseases

Received: May 241993

Accepted after revision December 311993
Asthma is now the most common occupational respiratory ailment $[1,2]$. More than 200 agents have been described as causing occupational asthma, including many low molecular weight agents [3].

Occupational asthma is occasionally accompanied by systemic symptoms compatible with "alveolar" involvement. This has been shown in the case of isocyanates [4], as was reviewed recently [5].

We describe the case of a subject who developed asthma with systemic symptoms, leucocytosis and functional evidence of lung parenchymal involvement after being exposed to a carboxylated linear polyester containing polyethylene terephthalate and polybutylene terephthalate incorporated into an electrostatic powder paint.

\section{Case report}

A 39 year old subject was referred with the following history. He had begun work as a painter in a factory where metallic shelves were made. The one-part pow- der paint was made of an epoxy resin $(86 \%)$ and a linear carboxylated polyester containing polyethylene terephthalate and polybutylene terephthalate (14\%). The paint was sprayed onto the metallic boards, which were then heated in $200^{\circ} \mathrm{C}$ ovens. The subject worked at the end of the production line next to the oven, removing the finished shelves. He had had no respiratory symptoms before beginning the job. Two to three weeks later, he developed symptoms of cough, shortness of breath, sweating and shivers at the end of a shift. These symptoms persisted in the evening for $3-4 \mathrm{~h}$. For one month he experienced the symptoms recurrently, although not daily, and never during weekends, at which time he was asymptomatic. He saw two physicians and was given an antibiotic. At the end of the month, he experienced a similar but more marked episode after being at work for $4 \mathrm{~h}$ and went to an emergency room. His oral temperature was $39^{\circ} \mathrm{C}$ and he showed bilateral wheezing on chest auscultation. His arterial oxygen tension $\left(\mathrm{PaO}_{2}\right)$ was slightly reduced at 58 torr $(7.7 \mathrm{kPa})$. 
The white blood count (WBC) was 17,000 cells $\cdot \mathrm{mm}^{-3}$. The chest radiograph was normal. Spirometry showed marked airway obstruction with a forced expiratory volume in one second $\left(\mathrm{FEV}_{1}\right)$ /forced vital capacity (FVC) ratio of 1.3/2.2 $l$, improving to 2.2./3.8 $l$ after $200 \mu \mathrm{g}$ of salbutamol was administered (predicted values $=3.4 / 4.1 l$ ) [6]. He was treated with an inhaled beta $_{2}$-adrenergic agent on an as needed basis and given oral prednisone for 2 weeks. He was kept in hospital for one week and, at the time he was discharged, his $\mathrm{FEV}_{1} / \mathrm{FVC}$ was $3.3 / 4.5 l$ (normal values). Lung volumes measured by body plethysmography were normal [7] and diffusing capacity of the lungs for carbon monoxide (DLCO) by the single-breath method was $83 \%$ pred [8]. He underwent a histamine inhalation challenge according to a standardized methodology [9] (output of the nebulizer $=0.14 \mathrm{ml} \cdot \mathrm{min}^{-1}$ ). The provocative concentration of histamine causing a $20 \%$ fall in $\mathrm{FEV}_{1}$ $\left(\mathrm{PC}_{20}\right)$ was $1.7 \mathrm{mg} \cdot \mathrm{ml}^{-1}$ corresponding to mild bronchial hyperresponsiveness [9].

The subject left his job and became asymptomatic except for chest tightness when he was exposed to cold air. Four months later specific inhalation tests were performed at the workplace by asking the subject to stand as an observer at his usual post (fig. 1). A control day of nonexposure in the hospital laboratory showed no significant changes in $\mathrm{FEV}_{1}$ or in buccal temperature. After $4 \mathrm{~h}$ at work, the subject developed a progressive fall in $\mathrm{FEV}_{1}$ that reached $23 \%$ after the last exposure period of $1 \mathrm{~h}$, and was maximal (40\%) $2 \mathrm{~h}$ later. There was associated fever $\left(38.9^{\circ} \mathrm{C}\right)$ shivers, headache and small crackles on auscultation of the lung bases. A WBC showed leucocytosis $\left(18,900\right.$ cells $\cdot \mathrm{mm}^{-3}$ with $86 \%$ neutrophils, $5 \%$ lymphocytes and $2 \%$ eosinophils). Chest radiograph was normal. Pulmonary function tests showed an obstructive pattern with an increase in all static lung volumes and diffusing capacity was reduced (table 1). The subject was given inhaled beclomethasone dipropionate (BDP) $(2,000 \mu \mathrm{g}$ daily) for two

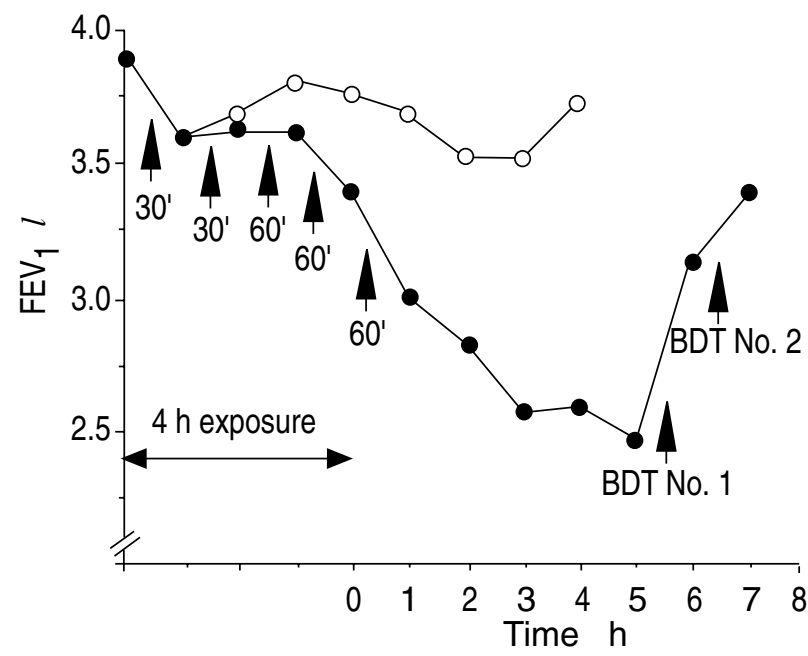

Fig. 1. - Changes in $\mathrm{FEV}_{1}$ on a control day ( $-\mathrm{O}-$ ) and after serial exposures at work (- ) for a total of $4 \mathrm{~h}$. BDT: inhaled beta ${ }_{2}$-adrenergic agent (salbutamol, $200 \mu \mathrm{g}$ ); $\mathrm{FEV}_{1}$ : forced expiratory volume in one second.
Table 1. - Changes in lung volumes and diffusing capacity of the lungs for carbon monoxide (DLCO) according to exposure

\begin{tabular}{lcccc}
\hline & $\begin{array}{c}\text { Predicted } \\
\text { value }\end{array}$ & $\begin{array}{c}\text { Control } \\
\text { value }\end{array}$ & $\begin{array}{c}\text { Exposure } \\
\text { at work }\end{array}$ & $\begin{array}{c}\text { Laboratory } \\
\text { challenges }\end{array}$ \\
\hline TLC $l$ & 6.2 & 7.4 & 8.3 & 7.9 \\
VC $l$ & 4.1 & 5.1 & 4.3 & 4.1 \\
FRC $l$ & 3.5 & 3.5 & 5.4 & 5.0 \\
RV $l$ & 2.0 & 2.3 & 4.0 & 3.8 \\
DLCO & 9.0 & 8.5 & 4.0 & 5.0
\end{tabular}

$\mathrm{mmol} \cdot \mathrm{min}^{-1}$

$\mathrm{kPa}$

Significant increases in total lung capacity (TLC), functional residual capacity (FRC) and residual volume (RV) with decreases in vital capacity (VC) and (DLCo) on a day of exposure to polyester at work and with specific inhalation challenges in the laboratory compared to control no-exposure day.

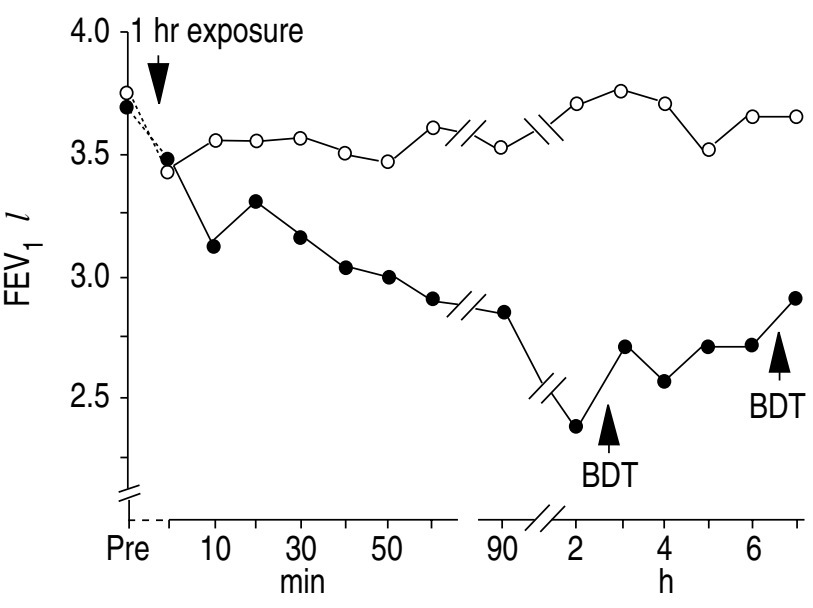

Fig. 2. - Results of specific inhalation challenges in the hospital laboratory. Control no-exposure day ( $-\mathrm{O}-$ ). Progressive exposure to the heated polyester resin for a total of one hour resulted in a progressive fall in $\mathrm{FEV}_{1}$ that peaked $2 \mathrm{~h}$ after exposure ended, requiring administration of inhaled salbutamol $(200 \mu \mathrm{g})(\mathrm{BDT})$ on two occasions ( $—$ ). For abbreviations see legend to table 1 .

weeks. He improved rapidly with spirometry and DLCO returning to normal.

Two months later, specific inhalation challenges were carried out in the hospital laboratory (fig. 2). Exposing the subject to the epoxy resin containing bisphenol based epoxide and heated at $100-200^{\circ} \mathrm{C}$ for $2 \mathrm{~h}$ did not elicit any significant changes in $\mathrm{FEV}_{1}$ or in buccal temperature. Exposure to the granulated polyester component of the paint provided by the employer and heated to $100-200^{\circ} \mathrm{C}$ for 60 min resulted in a $15 \%$ fall in $\mathrm{FEV}_{1}$ immediately after exposure ended. This was followed by a progressive fall in $\mathrm{FEV}_{1}$ that reached $41 \% 2 \mathrm{~h}$ later and required administration of an inhaled beta ${ }_{2}$-adrenergic agent on two occasions. Buccal temperature reached $39^{\circ} \mathrm{C}$ and the subject experienced shivers, headache and dyspnoea. There was evidence of leucocytosis (WBC 16,700 cells $\cdot \mathrm{mm}^{-3}\left(16.7 \times 10^{9}\right.$ cells $\left.\cdot l^{-1}\right)$, neutrophils $\left.=89 \%\right)$. There was an increase in lung volumes and DLCo fell (table 1). PC $_{20}$ was 0.43 $\mathrm{mg} \cdot \mathrm{ml}^{-1}$ one month later, and $0.22 \mathrm{mg} \cdot \mathrm{ml}^{-1}$ nine months after challenges were carried out. 
The information provided by a chemist was that the chemical formula for linear polyesters was close to phthalic acid compounds and that it could contain traces of trimellitic anhydride (TMA). We therefore decided to perform further testing, exposing the subject to this product by heating it to $100-200^{\circ} \mathrm{C}$ for $1,10,30$ and $60 \mathrm{~min}$ on different days. There were no significant changes in spirometry after these exposures. Furthermore, specific immunoglobulin $\mathrm{E}$ and $\mathrm{G}$ ( $\mathrm{IgE}$ and $\mathrm{IgG}$ ) to TMA coupled to human serum albumin (HSA) were assessed [10]; levels were within normal limits.

\section{Discussion}

This study shows that a low molecular weight agent, polyester (fig. 3), or one of its degradation products can cause occupational asthma when it is heated. The baseline structure of polyester is that of a low molecular weight agent although, when polymerized, it can be considered as a high molecular weight agent in the same way as isocyanates. This chemical should, therefore, be added to the list of causal agents [3]. Low molecular weight agents can cause isolated late reactions or dual reactions or atypical asthmatic reactions [11]. Our subject developed a progressive type of reaction that was maximal $2 \mathrm{~h}$ after exposure ended. The obstructive component was confirmed by a significant reduction in expiratory flow rates and changes in lung volume components. The subject also developed fever and leucocytosis, which are both sensitive and specific in detecting alveolitis-type reactions [12]. He showed a $50 \%$ fall in diffusing capacity, which may further show that an alveolar reaction occurred. Lung volumes showed hyperinflation, which is more typical of a bronchial component. These functional and systemic changes, therefore, suggest a "bronchioloalveolitis" type of reaction. However, we did not carry out a bronchoscopy with a bronchoalveolar lavage to confirm the alveolar involvement. The mechanism of the reaction in terms of possible involvement of specific $\operatorname{IgE}$ and IgG antibodies was not examined because it is rare that low molecular weight agents cause asthma in this way. Although we did not have means to assess the concentration of polyester and ensure that this was not "toxic", we feel that the reaction reflected possible "sensitization" to the product. The employee was indeed the only one to experience symptoms at work, whereas several other employees were also exposed in the same manner as the subject.

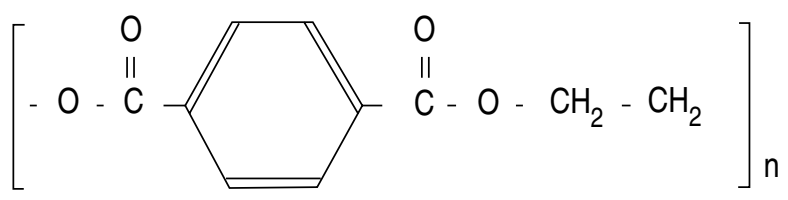

Fig. 3. - Chemical formula of a linear saturated polyester (polyethylene terephthalate).
Linear saturated polyesters can release various aldehydes (including acetaldehyde and acrolein) when heated. It would have been tedious to expose our subject to each of these various aldehydes, but we cannot exclude that one or other of them was responsible for the reaction. We excluded a reaction to trimellitic anhydride (TMA), which could have been present in traces in the saturated linear polyester. Exposing the subject for one hour to TMA did not induce any significant reaction.

Linear saturated polyesters were first used in the fabrication of fibres or films. Because of their resistive properties they have recently been used as plastics in mechanical and electrical industries. Heated polyester may, therefore, cause a respiratory and systemic reaction of a combined occupational asthma and alveolitis (bronchioloalveolitis) type. The prevalence of reaction caused by this agent remains to be examined.

Acknowledgements: The authors would like to thank J. Lesage of the Institut de recherche en santé et sécurité du travail for kindly providing useful chemical expertise and K. Tallman for reviewing the manuscript.

\section{References}

1. Meredith SK, Taylor VM, McDonald JC. Occupational respiratory disease in the United Kingdom 1989: a report to the British Thoracic Society and the Society of Occupational Medicine by the SWORD project group. Br J Ind Med 1991; 48: 292-298.

2. Lagier F, Cartier A, Malo JL. Statistiques médico-légales sur l'asthme professionnel au Québec de 1986 à 1988. Medico-legal statistics on occupational asthma in Quebec between 1986 and 1988. Rev Mal Respir 1990; 7: 337341.

3. Chan-Yeung M, Malo JL. Compendium 1. Table of the major inducers of occupational asthma. In: Bernstein IL, Chan-Yeung M, Malo JL, Bernstein DI. eds. Asthma in the Workplace. New York, Marcel Dekker Inc. 1993; pp. 595-623.

4. Malo JL, Ouimet G, Cartier A, Levitz D, Zeiss R. Combined alveolitis and asthma due to hexamethylene diisocyanate (HDI) with demonstration of crossed respiratory and immunologic reactivities to diphenylmethane diisocyanate (MDI). J Allergy Clin Immunol 1983; 72: 413-419.

5. Vandenplas O, Malo JL, Saetta M, Mapp CE, Fabbri L. Occupational asthma and extrinsic alveolitis due to isocyanates: current status and perspectives. $\mathrm{Br} J$ Ind Med 1993; 50: 213-228.

6. Knudson RJ, Lebowitz MD, Holberg CJ, Burrows B. Changes in the normal maximal expiratory flow-volume curve with growth and aging. Am Rev Respir Dis 1983; 127: 725-734.

7. Goldman HI, Becklake MR. Respiratory function tests. Normal values at median altitudes and the prediction of normal results. Am Rev Tuberc 1959; 79: 457467.

8. Miller A, Thornton JC, Warshaw R, Anderson H, Teirstein AS, Selikoff IJ. Single breath diffusing capacity in a representative sample of population of Michigan, a large industrial state. Predicted values, lower 
limits of normal, and frequencies of abnormality by smoking history. Am Rev Respir Dis 1983; 127: 270-277.

9. Malo JL, Pineau L, Cartier A, Martin RR. Reference values of the provocative concentrations of methacholine that cause $6 \%$ and $20 \%$ changes in forced expiratory volume in one second in a normal population. Am Rev Respir Dis 1983; 128: 8-11.

10. Grammer LC, Shaughnessy MA, Henderson J, et al. A clinical and immunologic study of workers with trimellitic-anhydride-induced immunologic lung dis- ease after transfer to low exposure jobs. Am Rev Respir Dis 1993; 148: 54-57.

11. Perrin B, Cartier A, Ghezzo H, et al. Reassessment of the temporal patterns of bronchial obstruction after exposure to occupational sensitizing agents. J Allergy Clin Immunol 1991; 87: 630-639.

12. Hendrick DJ, Marshall R, Faux JA, Krall JM. Positive "alveolar" responses to antigen inhalation provocation tests: their validity and recognition. Thorax 1980; 35: 415-427. 